\title{
MENGUKUR TINGKAT KENYAMANAN PENGUNJUNG TAMAN BUAH MEKARSARI BOGOR MENGGUNAKAN METODE FUZZY MAMDANI
}

\author{
Samsul Ma'arif ${ }^{1}$; Sfenrianto ${ }^{2}$; Edhi Prayitno ${ }^{3}$ \\ ${ }^{1}$ Program Studi Sistem Informasi \\ STMIK Mercusuar \\ samsulmaarif056@gmail.com \\ 2Program Studi Ilmu Komputer \\ STMIK Nusa Mandiri Jakarta \\ sfenrianto.71@gmail.com \\ ${ }^{3}$ Program Studi Sistem Informasi \\ STMIK Nusa Mandiri Jakarta \\ edhi.epo@nusamandiri.ac.id
}

\begin{abstract}
Mekarsari Fruit Park is one of the domestic tourist destinations in Bogor, West Java, which is quite visited. The application of the Fuzzy Inference System (FIZ) is used to measure the level of comfort of visitors at Mekarsari Fruit Park. The visitor's comfort level refers to 3 (three) criteria for variables used, such as service, facilities and cleanliness. Each variable has a number of indicators, that is 5 questions on service variables, 5 questions on facility variables and 3 questions on cleanliness variables. The method used is the Mamdani method by using max-min, who has a membership degree min. 0 and max. 1. Then the defuzzyfication process was carried out to get the results of the study which showed the influence of the quality of visitors on the comfort given. The comfort level measurements of the Mekarsari Fruit Garden with the Mamdani method used Matlab software 7.9 is 5.37. The results of the Mamdani method stated that they were quite satisfied with the comfort given of Mekarsari Fruit Park visitors.
\end{abstract}

Keywords: Fuzzy Inference System (Fiz), Matlab, Mamdani Method, Comfort Level.

Intisari-Taman Buah Mekarsari merupakan salah satu destinasi wisatawan domestik yang berada di Bogor, Jawa Barat yang cukup banyak mendapat kunjungan. Penerapan Fuzzy Inference System (FIZ) digunakan untuk mengukur tingkat kenyamanan pengunjung pada Taman Buah Mekarsari. Tingkat kenyamanan pengunjung mengacu kepada 3 (tiga) kriteria variabel yang digunakan yaitu pelayanan, fasilitas dan kebersihan. Masing-masing variabel memiliki sejumlah indikator, yaitu 5 pertanyaan pada variabel pelayanan, 5 pertanyaan pada variabel fasilitas dan 3 pertanyaan pada variabel kebersihan. Metode fuzzy yang digunakan adalah metode Mamdani dengan menggunakaan max-min yang memiliki derajat keanggotaan min. 0 dan max.1. Lalu dilakukan proses defuzzyfikasi

untuk mendapatkan hasil penelitian yang menunjukan pengaruh antara kualitas pengunjung terhadap kenyamanan yang diberikan. Pengukuran tingkat kenyamanan Taman Buah Mekarsari dengan metode Mamdani menggunakan software Matlab 7.9 sebesar 5,37. Hasil dari metode Mamdani menyatakan cukup puas terhadap kenyamanan yang diberikan kepada pengunjung Taman Buah Mekarsari.

Kata Kunci: Fuzzy Inference System (Fiz), Matlab, Metode Mamdani, Tingkat Kenyamanan.

\section{PENDAHULUAN}

Kegiatan wisata atau travelling sudah menjadi kebutuhan primer masyarakat yang cenderung untuk bepergian lebih lama, lebih jauh dan lebih sering(Dempsey, 2015). Kebutuhan akan wisata tidak hanya untuk kalangan tertentu saja namun juga untuk semua kalangan tanpa memandang usia maupun gender, berdasarkan data yang dirilis oleh Badan Pusat Statistik. 
Tabel 1. Jumlah Kunjungan Wisata ke Objek Wisata Unggulan Menurut Lokasi 2011-2015

\begin{tabular}{llrrrrr}
\hline & \multirow{2}{*}{ Lokasi } & \multicolumn{5}{c}{ Tahun } \\
\cline { 3 - 7 } & \multicolumn{1}{c}{$\mathbf{1}$} & $\mathbf{2 0 1 1}$ & $\mathbf{2 0 1 2}$ & $\mathbf{2 0 1 3}$ & $\mathbf{2 0 1 4}$ & $\mathbf{2 0 1 5}$ \\
\hline & & $\mathbf{2}$ & $\mathbf{3}$ & $\mathbf{4}$ & $\mathbf{5}$ & $\mathbf{6}$ \\
\hline 1 & Ancol & 18450016 & 15848956 & 15948829 & 16085604 & 16661517 \\
\hline 2 & TMII & 5186445 & 7888787 & 4483847 & 4587735 & 5575905 \\
\hline 3 & Ragunan & 4090567 & 4283895 & 3681968 & 4100570 & 5157035 \\
\hline 4 & Monas & 1516153 & 1418469 & 1380868 & 1156208 & 1539195 \\
\hline 5 & Museum Nasional & 193864 & 148118 & 169527 & 245848 & 266359 \\
\hline 6 & Museum S. Mandala & 74742 & 50818 & 46002 & 38756 & 49964 \\
\hline 7 & Museum Sejarah & 437040 & 396253 & 371467 & 196433 & 535144 \\
\hline 8 & Pelabuhan Sunda Kelapa & 34179 & 32067 & 40210 & 50779 & 63220 \\
\hline & \multirow{2}{*}{ Jumlah } & $\mathbf{2 9 9 8 3 0 0 6}$ & $\mathbf{3 0 0 6 7 3 6 3}$ & $\mathbf{2 6 1 2 2 ~ 7 1 8}$ & $\mathbf{2 6 4 6 1 9 3 3}$ & $\mathbf{2 9 8 4 8}$ \\
& & & & & $\mathbf{3 3 9}$ \\
\hline
\end{tabular}

Sumber: (Badan Pusat Statistik, 2017)

Salah satu faktor penyebab tingginya kunjungan ke tempat objek wisata adalah laju urbanisasi yang cepat, sehingga kepadatan penduduk perkotaan semakin tinggi dan berimplikasi pada keterbatasan ruang untuk melakukan relaksasi(Damanik, 2014). Pada umumnya saat liburan secara rutin sebagian besar masyarakat suka menghabiskan waktunya untuk berkunjung ke tempat objek wisata yang menawarkan fasilitas yang menyenangkan seperti Taman Impian Jaya Ancol, TMII, Kebun Raya Bogor, Kebun Binatang Ragunan, dan sebagainya.

Menurut Yoeti (Yoeti, 2003) fasilitas wisata adalah semua fasilitas yang fungsinya memenuhi kebutuhan wisatawan yang tinggal untuk sementara waktu di daerah tujuan wisata yang dikunjunginya, dimana mereka dapat santai menikmati dan berpartisipasi dalam kegiatan yang tersedia di daerah tujuan wisata tersebut. Wisata alam merupakan salah satu bagian dari kegiatan wisata yang mencakup banyak kegiatan, mulai dari kegiatan menikmati pemandangan dan kehidupan liar yang relatif pasif, sampai kegiatan fisik seperti wisata petualangan yang sering mengandung resiko(Sastrayuda, 2010).

Taman Buah Mekarsari sebagai salah satu objek wisata di daerah Bogor menyediakan fasilitas keluarga berkebun buah dan permainan yang dirancang alami untuk kembali ke alam. Hal ini sesuai dengan pandangan dimana fasilitas wisata dan harga terbukti memiliki pengaruh yang sangat signifikan terhadap kepuasan konsumen(Sulistiyana, Hamid, \& Azizah, 2015). Kemampuan untuk memetakan potensi sumber daya yang dimiliki menjadi hal yang penting untuk meningkatkan kepuasan pengunjung. Tingkat kepuasan pengunjung menjadi ukuran keberhasilan suatu objek wisata dalam bersaing atau berkompetisi sehingga dapat bertahan dan berkembang dengan baik. Persepsi nilai kepuasan pengunjung terhadap pelayanan suatu objek wisata yang ada masih sulit dilakukan secara manual sehingga perlu diukur secara ilmiah untuk mengetahui secara akurat sejauhmana pandangan pengunjung terhadap pelayanan yang mereka terima secara objektif.

Tujuan dari penelitian ini adalah mengetahui tingkat kepuasan pengunjung Taman Buah Mekarsari menggunakan metode fuzzy Mamdani sehingga pihak pengelola objek wisata dapat mengambil manfaat dan berbenah lebih baik lagi memperbaiki pelayanan maupun infrastruktur penunjang yang ada.

Pada penelitian ini metode yang digunakan penulis adalah metode penelitian kuantitatif. Penulis membagikan kuisioner kepada pengunjung untuk mengisi pilihan terhadap beberapa variabel berikut dengan skor penilaiannya yang nantinya akan diolah menggunakan metode fuzzy Mamdani.

Metode fuzzy Mamdani merupakan bagian dari Fuzzy Inference System (FIZ) yang merupakan logika fuzzy untuk melakukan analisis sistem yang mengandung ketidakpastian. Logika fuzzy cukup mampu untuk memetakan suatu input ke dalam output tanpa mengabaikan faktor-faktor yang ada. Logika fuzzy sangat berguna untuk menyelesaikan banyak permasalahan dalam berbagai bidang yang biasanya memuat derajat ketidakpastian(Gokmen, Akinci, Tektas, 2010).

Kenyamanan dan perasaan nyaman adalah penilaian komprehensif seorang terhadap lingkungannya(Satwiko, 2009). Manusia menilai kondisi lingkungan berdasarkan rangsangan yang masuk ke dalam dirinya melalui keenam indera melalui syaraf dan dicerna otak untuk dinilai. Dalam hal ini yang terlibat tidak hanya masalah fisik biologis, namun juga perasaan. Suara, cahaya bau, suhu dan lain-lain rangsangan ditangkap sekaligus. Lalu diolah oleh otak. Kemudian otak akan memberikan penilaian relatif apakah kondisi itu nyaman atau tidak. Ketidaknyamanan di satu faktor dapat ditutupi oleh faktor lain.

Menurut Kusumadewi dan Purnomo (Kusumadewi, S., \& Purnomo, 2010) dasar logika fuzzy adalah teori himpunan fuzzy, pada teori himpunan fuzzy peranan derajat keanggotaan sebagai penentu keberadaan elemen dalam suatu 
himpunan sangatlah penting. Nilai keanggotaan atau derajat keanggotaan sebagai penentu keberadaan elemen dalam suatu himpunan sangatlah penting. Nilai keanggotaan atau derajat keanggotaan atau membership function menjadi ciri utama dari penalaran dengan logika fuzzy tersebut. Dalam banyak hal, logika fuzzy digunakan sebagai suatu cara untuk memetakan permasalahan dari input menuju ke output yang diharapkan.

Untuk mendapatkan output pada metode Mamdani diperlukan 4 tahapan yaitu(Kusumadewi, S., \& Purnomo, 2010):

1. Pembentukan himpunan fuzzy

Pada metode Mamdani, baik variabel input maupun variabel output dibagi menjadi satu atau lebih himpunan fuzzy.

2. Aplikasi fungsi implikasi

Pada metode Mamdani, fungsi implikasi yang digunakan adalah Min.

3. Komposisi aturan

Pada metode ini, solusi himpunan fuzzy diperoleh dengan cara mengambil nilai maksimum aturan, kemudian menggunakannya untuk memodifikasi daerah fuzzy, dan mengaplikasikannya ke output dengan menggunakan operator $O R$ (union).

4. Penegasan (DeFuzzy)

Input dari proses defuzzifikasi adalah suatu himpunan fuzzy yang diperoleh dari komposisi aturan-aturan fuzzy, sedangkan output yang dihasilkan merupakan suatu bilangan pada domain himpunan fuzzy tersebut.

Berikut gambar flowchart metode Mamdani:

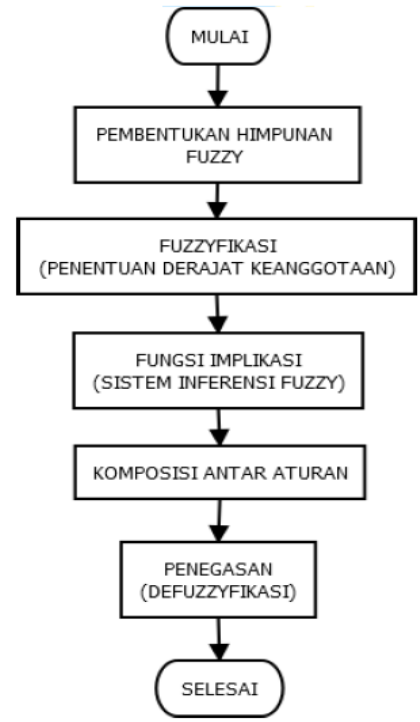

Sumber: (Kusumadewi, S., \& Purnomo, 2010)

Gambar 1. Flowchart Metode Mamdani

Fungsi keanggotaan mendefinisikan bagaimana derajat keanggotaan dari suatu elemen dan sekaligus merepresentasikan suatu parameter di dunia nyata. Beberapa fungsi keanggotaan sederhana yang umum digunakan adalah:

1. Representasi Linier/Bahu

Reperesentasi ini paling sederhana dan terbagi dua berdasarkan gradiennya, yaitu Linier Naik (Bahu Kanan) dan Linier Turun (Bahu Kiri).

a. Fungsi keanggotaan Linier Naik/Bahu Kanan:

$$
\mu(x)=\left\{\begin{array}{cl}
0 ; & \\
\frac{x-a}{b-a} ; & x \leq a \\
1 ; & a \leq x \leq b \\
& x \geq b
\end{array}\right.
$$

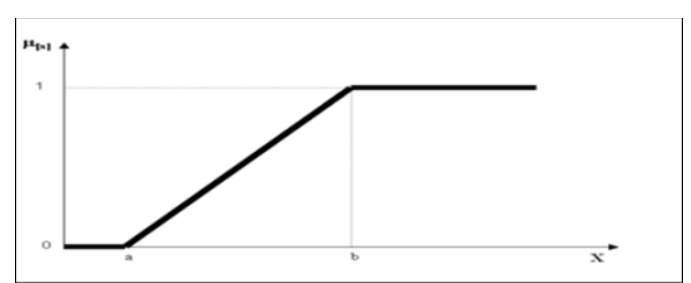

Sumber: (Kusumadewi, S., \& Purnomo, 2010)

Gambar 2. Grafik Fungsi Keanggotaan Linier Naik

b. Fungsi keanggotaan Linier Turun/Bahu Kiri:

$$
\mu(x)= \begin{cases}1 ; & \\ \frac{b-x}{b-a} ; & x \leq a \\ 0 ; & a \leq x \leq b\end{cases}
$$

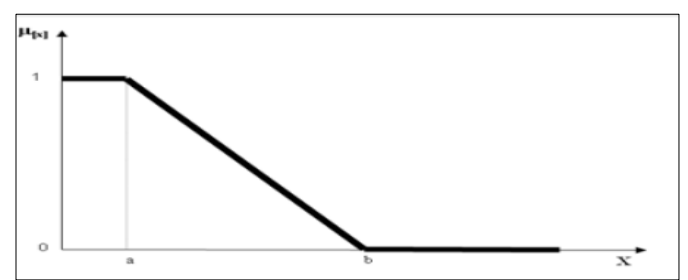

Sumber: (Kusumadewi, S., \& Purnomo, 2010)

Gambar 3. Grafik Fungsi Keanggotaan Linier Turun

2. Representasi Kurva Segitiga

Representasi ini merupakan gabungan dua kurva, yaitu linier naik dan linier turun.

$$
\mu(x)=\left\{\begin{array}{cc}
1 ; & \\
\frac{b-x}{b-a} ; & \\
\frac{c-x}{c-b} ; & (x \leq a) V(x \geq c) \\
& a \leq x \leq b \\
& b \leq x \leq c
\end{array}\right.
$$

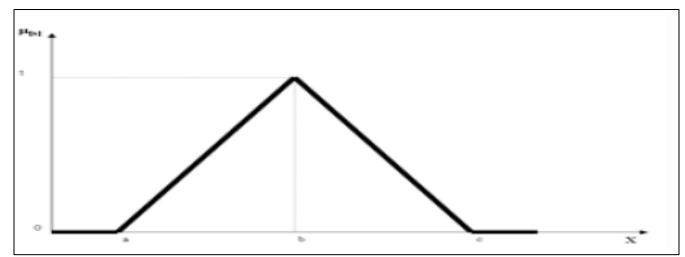

Sumber: (Kusumadewi, S., \& Purnomo, 2010)

Gambar 4. Grafik Fungsi Keanggotaan Kurva Segitiga 
3. Representasi Kurva Travesium

Representasi kurva trapesium pada dasarnya serupa dengan kurva segitiga namun memiliki banyak titik yang memiliki nilai keanggotaan 1.

$\mu(x)=\left\{\begin{array}{cc}0 ; \mathrm{x} \leq \mathrm{a} \text { atau } \mathrm{x} \geq \mathrm{d} \\ \frac{x-a}{b-a} ; & \mathrm{a} \leq \mathrm{x} \leq \mathrm{b} \\ 1 ; & \mathrm{b} \leq \mathrm{x} \leq \mathrm{c} \\ \frac{d-x}{d-c} ; & x \geq d\end{array}\right.$

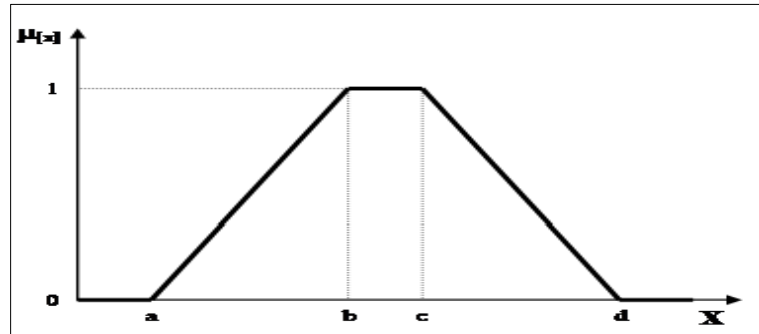

Sumber: (Kusumadewi, S., \& Purnomo, 2010)

Gambar 5. Grafik Fungsi Keanggotaan Kurva Travesium

4. Representasi Kurva-S

Kurva-S didefinisikan dengan menggunakan 3 parameter, yaitu: nilai keanggotaan nol (a), nilai keanggotaan lengkap (y), dan titik infleksi atau crossover ( $ß)$.

Fungsi keanggotaan yang digunakan adalah fungsi sigmoid. Dapat dibedakan menjadi kurva-S Naik serta kurva-S Turun.

a. Kurva-S Naik

$S(x ; a, \beta, \gamma)=\left\{\begin{array}{cc}0 ; & \mathrm{x} \leq \mathrm{a} \\ 2\left(\frac{x-a}{y-a}\right) ; & \mathrm{a} \leq \mathrm{x} \leq \beta \\ 1-2\left(\frac{x-a}{y-a}\right) ; & \beta \leq \mathrm{x} \leq \gamma \\ & 1 ; x \geq \gamma\end{array}\right.$

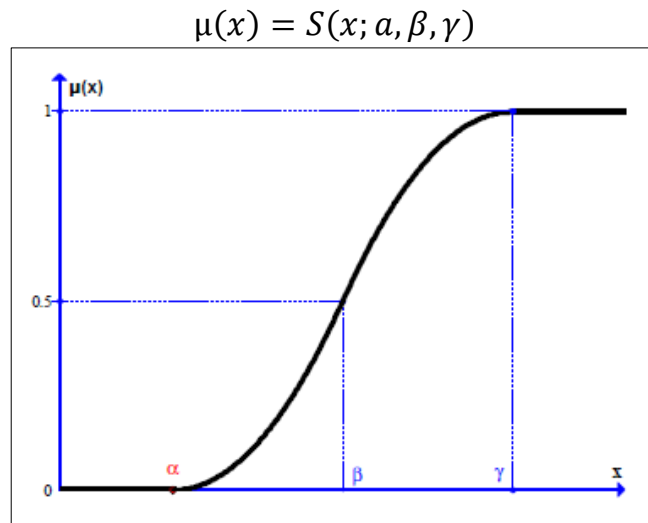

Sumber: (Kusumadewi, S., \& Purnomo, 2010)

Gambar 6. Grafik Fungsi Keanggotaan Kurva-S Naik b. Kurva-S Turun

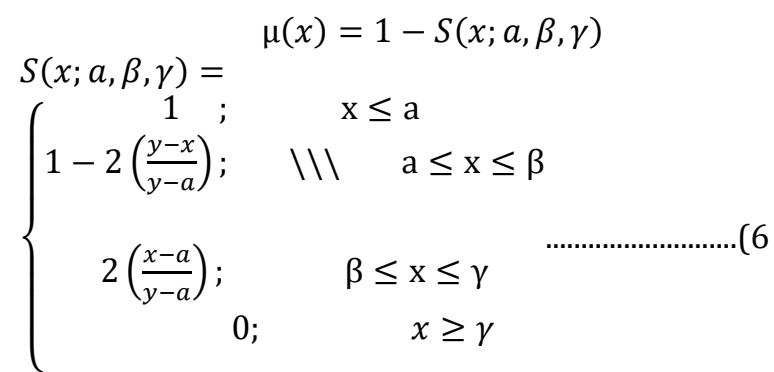

)

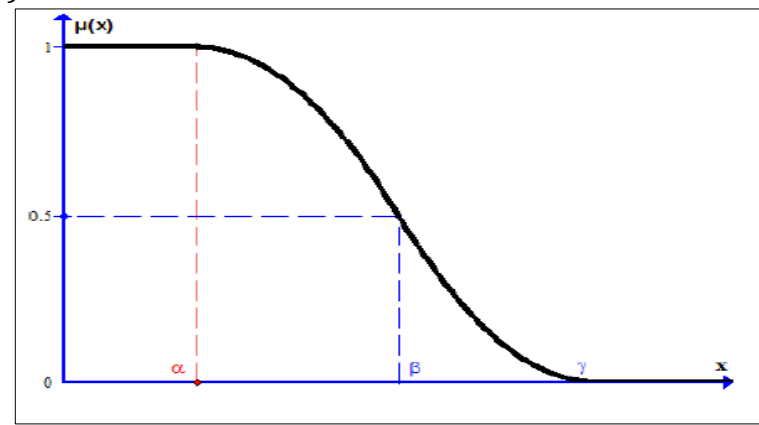

Sumber: (Kusumadewi, S., \& Purnomo, 2010) Gambar 7. Grafik Fungsi Keanggotaan Kurva-S Turun

5. Representasi Kurva Lonceng (Bell Curve) Terdapat banyak fungsi yang membentuk kurva lonceng. Tiga diantaranya adalah fungsi Pi, Beta dan Gauss.

\section{a. Kurva Pi:}

$\mu(x)=\pi(x ; \beta, \gamma)=$ $\begin{cases}S\left(x ; \gamma-\beta, \gamma-\frac{\beta}{2} y\right) ; & \mathrm{x} \leq \mathrm{y} \\ S\left(x ; \gamma, \gamma+\frac{\beta}{2} y+\beta\right) ; & \mathrm{x} \leq \gamma\end{cases}$

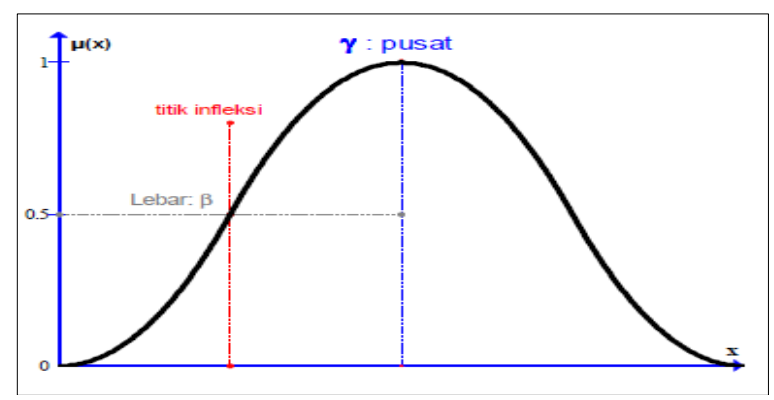

Sumber: (Kusumadewi, S., \& Purnomo, 2010) Gambar 8. Grafik Fungsi Keanggotaan Kurva Pi 
b. Kurva Beta:

$\mu(x)=B(x ; \gamma, \beta)=\frac{1}{1+\left(\frac{x-y}{\beta}\right)^{2}}$

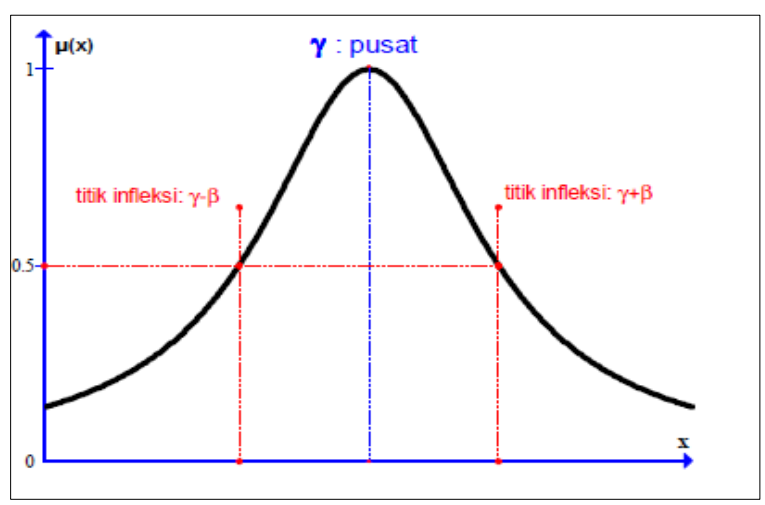

Sumber: (Kusumadewi, S., \& Purnomo, 2010)

Gambar 9. Grafik Fungsi Keanggotaan Kurva Beta

c. Kurva Gauss:

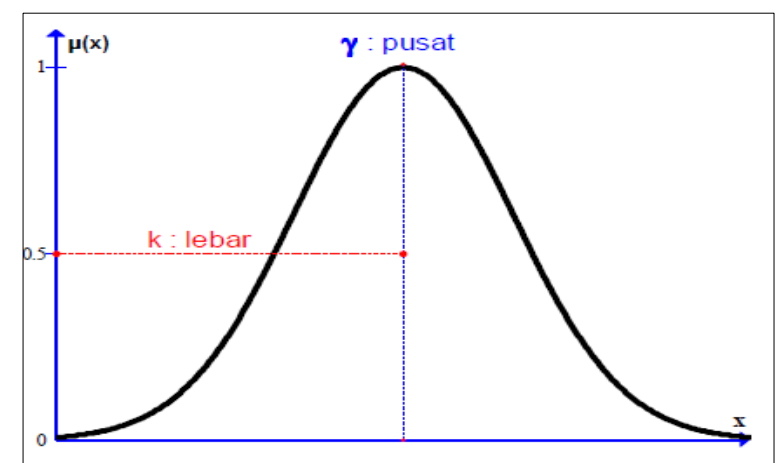

Sumber: (Kusumadewi, S., \& Purnomo, 2010)

Gambar 10. Grafik Fungsi Keanggotaan Kurva Gauss

\section{BAHAN DAN METODE}

Skala Likert adalah skala yang dapat dipergunakan untuk mengukur sikap, pendapat dan persepsi seseorang atau sekelompok orang tentang fenomena sosial. Dengan Skala Likert, maka variabel yang akan diukur dijabarkan menjadi indikator variabel, dan indikator tersebut dijadikan sebagai titik tolak ukur menyusun item-item instrumen yang dapat berupa pertanyaan atau pernyataan.

Pada penelitian ini terdapat 3 (tiga) kriteria variabel yang digunakan yaitu pelayanan, fasilitas dan kebersihan. Masing-masing variabel memiliki sejumlah indikator tersendiri yaitu 5 pernyataan pada variabel pelayanan, 5 pernyataan pada variabel fasilitas, dan 3 pernyataan pada variabel kebersihan.

Berikut gambaran kerangka pemikiran penelitian.

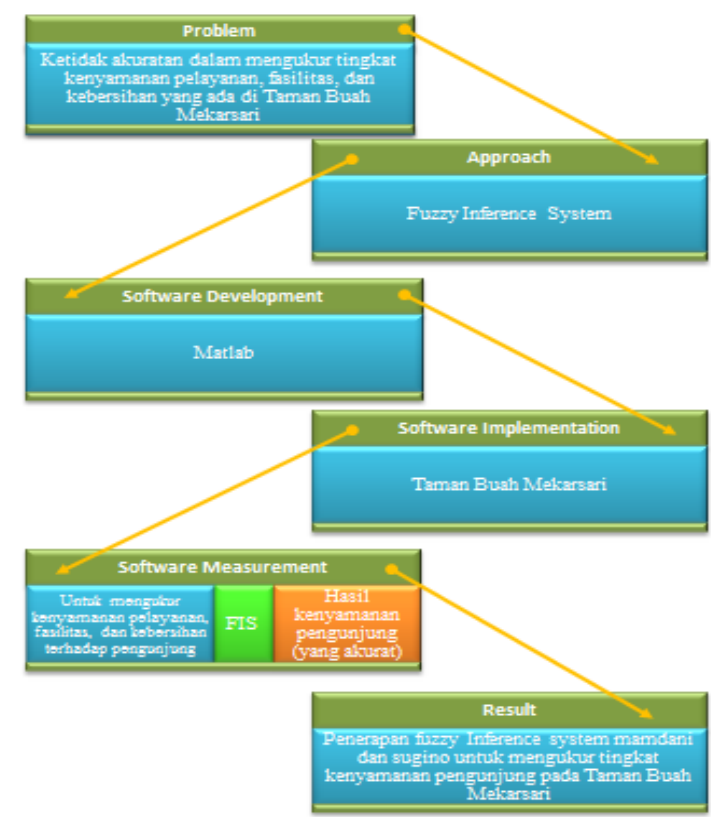

Sumber: (Ma'arif, Samsul ; Sfenrianto; Prayitno, 2019)

Gambar 11. Kerangka Pemikiran Penelitian

Berikut tabel variabel dan indikator dalam penilaian kenyamanan pengunjung.

Tabel 2. Variabel dan Indikator dalam Penilaian Kenyamanan Pengunjung

\begin{tabular}{|c|c|}
\hline Variabel & Pernyataan \\
\hline Pelayanan & $\begin{array}{l}\text { Petugas wisata dapat memberikan } \\
\text { informasi yang tepat mengenai wahana } \\
\text { dan fasilitas yang ada di Taman Buah } \\
\text { Mekarsari. }\end{array}$ \\
\hline
\end{tabular}

2. Petugas wisata selalu rapi, senyum, ramah, sopan kepada pengunjung.

3. Petugas memberikan tanggapan mengenai keluhan pengunjung.

1. Petugas wisata melayani para pengunjung secara professional.

5. Taman Buah Mekarsari dapat memberikan suasana nyaman kepada pengunjung.

\begin{tabular}{|c|c|}
\hline \multirow{7}{*}{ Fasilitas } & 1. Fasilitas toilet yang bagus. \\
\hline & 2. Fasilitas kantin yang lengkap. \\
\hline & 3. Fasilitas tempat ibadah yang indah. \\
\hline & $\begin{array}{l}\text { 4. Taman Buah Mekarsari memiliki ruang } \\
\text { atau tempat serbaguna }\end{array}$ \\
\hline & $\begin{array}{l}\text { (untuk wedding dan perpisahan) yang } \\
\text { lengkap. }\end{array}$ \\
\hline & $\begin{array}{l}\text { 5. Taman Buah Mekarsari dapat } \\
\text { menyediakan wahana kembali ke }\end{array}$ \\
\hline & $\begin{array}{l}\text { alam (menanam pohon, memetik buah dan } \\
\text { lain-lain). }\end{array}$ \\
\hline \multirow{4}{*}{ Kebersihan } & 1. Kebersihan disetiap lokasi dapat terjaga. \\
\hline & $\begin{array}{l}\text { 2. Kebersihan Taman Buah Mekarsari lebih } \\
\text { terjaga }\end{array}$ \\
\hline & dibandingkan tempat wisata yang lain. \\
\hline & $\begin{array}{l}\text { 3. Kebersihan fasilitas umum (musholla \& } \\
\text { toilet) terjaga. }\end{array}$ \\
\hline
\end{tabular}

Sumber: (Ma'arif, Samsul ; Sfenrianto; Prayitno, 2019) 
Terdapat beberapa metode defuzzifikasi yaitu:

1. Centroid Method

Metode ini dikenal juga sebagai Center of Area (CoA) atau Center of Gravity (CoG). Rumus yang digunakan adalah:

$\mathrm{y}^{*}=\frac{\int y \mu R(y) d y}{\mu R(y) d y}$

Namun jika nilai y berupa nilai diskrit, maka dapat digunakan rumus:

$y *=\frac{\sum y \mu R(y)}{\sum \mu R(y)}$

2. Height Method

Metode ini dikenal juga sebagai metode singleton atau keanggotaan maksimum, karena secara sederhana akan memilih nilai tegas (crisp) yang memiliki derajat keanggotaan maksimum, yaitu:

1. First of Maxima/Last of Maxima Method Metode ini merupakan generalisasi dari height method dimana fungsi keanggotaan output dapat memiliki lebih dari satu nilai maksimum, oleh karenanya akan dipilih nilai maksimum pertama atau nilai maksimum terakhir, tergantung aplikasi yang dibuat.

2. Mean-Max Method

Metode ini dikenal juga sebagai Middle of Maxima. Metode ini juga merupakan generalisasi dari height method, namun akan memilih nilai tengah dari nilai tegas dengan derajat keanggotaan maksimum, dengan rumus:

$$
\mathrm{y}^{*}=\frac{m+M}{2}
$$

Dimana $\mathrm{m}$ adalah nilai tegas yang terkecil dan $\mathrm{M}$ adalah nilai tegas yang terbesar.

3. Weighted Average Method

Metode ini mengambil nilai rata-rata dengan menggunakan pembobotan yang diambil dari nilai derajat keanggotaan, yaitu dengan rumus:

$$
\mathrm{y}^{*}=\Sigma \frac{\mu(y) \cdot y}{\mu(y)}
$$

Dimana y adalah nilai tegas dan $\mu(y)$ adalah derajat keanggotaan dari nilai y tersebut.

Tabel 3. Fungsi Keanggotaan Kenyamanan Pelayanan

\begin{tabular}{lll}
\hline No. & Fungsi Keanggotaan & Rentang Nilai \\
\hline 1 & Kurang & $0-5$ \\
\hline 2 & Cukup & $4-8$ \\
\hline 3 & Baik & $7-10$ \\
\hline \multicolumn{2}{l}{ Sumber: (Kusumadewi, S., \& Purnomo, 2010) }
\end{tabular}

Sumber: (Kusumadewi, S., \& Purnomo, 2010)

\begin{tabular}{|c|c|c|}
\hline Variabel & $\begin{array}{l}\text { Himpunan } \\
\text { Fuzzy }\end{array}$ & Domain \\
\hline Tingkat & Kurang & {$\left[\begin{array}{lll}0 & 0 & 5\end{array}\right]$} \\
\hline Pelayanan & $\begin{array}{l}\text { Cukup } \\
\text { Baik }\end{array}$ & $\begin{array}{l}{\left[\begin{array}{lll}4 & 4 & 8\end{array}\right]} \\
{\left[\begin{array}{llll}7 & 7 & 10\end{array}\right]}\end{array}$ \\
\hline Tingkat & Kurang & {$\left[\begin{array}{lll}0 & 0 & 5\end{array}\right]$} \\
\hline Fasilitas & $\begin{array}{l}\text { Cukup } \\
\text { Baik }\end{array}$ & $\begin{array}{l}{\left[\begin{array}{lll}4 & 4 & 8\end{array}\right]} \\
{\left[\begin{array}{lll}7 & 7 & 10\end{array}\right]}\end{array}$ \\
\hline $\begin{array}{l}\text { Tingkat } \\
\text { Kebersihan }\end{array}$ & $\begin{array}{l}\text { Kurang } \\
\text { Cukup } \\
\text { Baik }\end{array}$ & $\left.\begin{array}{l}{\left[\begin{array}{lll}0 & 0 & 5\end{array}\right]} \\
{\left[\begin{array}{lll}4 & 4\end{array}\right]}\end{array}\right]$ \\
\hline
\end{tabular}

Tabel 4. Himpunan Fuzzy

Sumber: (Ma'arif, Samsul ; Sfenrianto; Prayitno, 2019)

Pada variabel ini Himpunan fuzzy kurang akan memiliki domain $[0,5]$ dimana derajat keanggotaan Kurang tertinggi $(=1)$ terletak pada angka 0-4. Himpunan fuzzy cukup memiliki domain [4-8] dimana derajat keanggotaan Cukup tertinggi $(=1)$ terletak pada nilai 6. Himpunan fuzzy baik akan memiliki domain $[7,10]$ dimana derajat keanggotaan Baik tertinggi $(=1)$ terletak pada angka $>=8$.

Variabel pelayanan petugas wisata memberikan informasi yang tepat mengenai wahana dan fasilitas yang ada di Taman Buah Mekarsari. Representasi dengan grafik dapat digambarkan sebagai berikut.

Derajat Keanggotaan $\mu(\mathrm{a})$

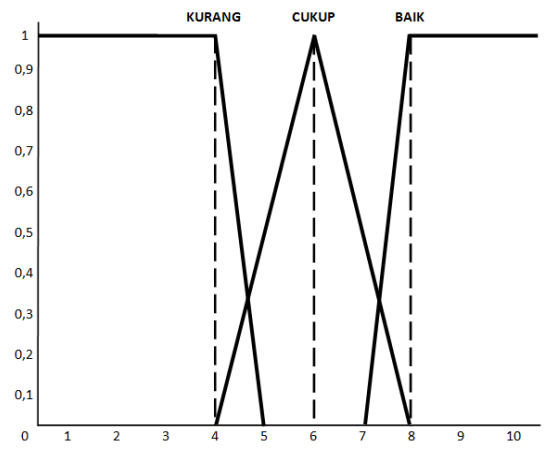

Sumber: (Ma'arif, Samsul ; Sfenrianto; Prayitno, 2019)

Gambar 12. Grafik Fungsi Keanggotaan Petugas Memberi Informasi yang Tepat Mengenai Wahana dan Fasilitas di Taman Buah Mekarsari

Komposisi aturan fungsi implikasi menggunakan fungsi $M A X$ yaitu dengan cara mengambil nilai maksimum dari output aturan. Jika semua proposisi telah dievaluasi, maka output akan berisi suatu himpunan fuzzy yang merefleksikan konstribusi dari tiap-tiap proposisi.

Derajat kebenaran himpunan baik $=\operatorname{Max}(\alpha ; \alpha)=$ Max (1).

Daerah hasil inferensi tertinggi adalah 1 dan terendah 0 . 


\section{HASIL DAN PEMBAHASAN}

Dengan mengkombinasikan himpunan-himpunan fuzzy tersebut, maka di peroleh aturan fuzzy sebagai berikut:

[R1] IF Pelayanan KURANG And Fasilitas KURANG And Kebersihan KURANG THEN Kenyamanan KURANG

[R2] IF Pelayanan CUKUP And Fasilitas KURANG And Kebersihan KURANG THEN Kenyamanan KURANG

[R3] IF Pelayanan BAIK And Fasilitas KURANG And Kebersihan KURANG THEN Kenyamanan KURANG

[R4] IF Pelayanan KURANG And Fasilitas CUKUP And Kebersihan KURANG THEN Kenyamanan KURANG

[R5] IF Pelayanan KURANG And Fasilitas BAIK And Kebersihan KURANG THEN Kenyamanan KURANG

[R6] IF Pelayanan KURANG And Fasilitas KURANG And Kebersihan CUKUP THEN Kenyamanan KURANG

[R7] IF Pelayanan KURANG And Fasilitas KURANG And Kebersihan BAIK THEN Kenyamanan KURANG

[R8] IF Pelayanan CUKUP And Fasilitas CUKUP And Kebersihan CUKUP THEN Kenyamanan CUKUP

[R9] IF Pelayanan KURANG And Fasilitas CUKUP And Kebersihan CUKUP THEN Kenyamanan CUKUP

[R10] IF Pelayanan BAIK And Fasilitas CUKUP And Kebersihan CUKUP THEN Kenyamanan CUKUP

[R11] IF Pelayanan CUKUP And Fasilitas KURANG And Kebersihan CUKUP THEN Kenyamanan CUKUP

[R12] IF Pelayanan CUKUP And Fasilitas BAIK And Kebersihan CUKUP THEN Kenyamanan CUKUP

[R13] IF Pelayanan CUKUP And Fasilitas CUKUP And Kebersihan KURANG THEN Kenyamanan CUKUP

[R14] IF Pelayanan CUKUP And Fasilitas CUKUP And Kebersihan BAIK THEN Kenyamanan CUKUP

[R15] IF Pelayanan BAIK And Fasilitas BAIK And Kebersihan BAIK THEN Kenyamanan BAIK

[R16] IF Pelayanan KURANG And Fasilitas BAIK And Kebersihan BAIK THEN Kenyamanan BAIK

[R17] IF Pelayanan CUKUP And Fasilitas BAIK And Kebersihan BAIK THEN Kenyamanan BAIK

[R18] IF Pelayanan BAIK And Fasilitas KURANG And Kebersihan BAIK THEN Kenyamanan BAIK
[R19] IF Pelayanan BAIK And Fasilitas CUKUP And Kebersihan BAIK THEN Kenyamanan BAIK

[R20] IF Pelayanan BAIK And Fasilitas BAIK And Kebersihan KURANG THEN Kenyamanan BAIK

[R21] IF Pelayanan BAIK And Fasilitas BAIK And Kebersihan CUKUP THEN Kenyamanan BAIK

[R22] IF Pelayanan BAIK And Fasilitas KURANG And Kebersihan CUKUP THENKenyamanan CUKUP

[R23] IF Pelayanan CUKUP And Fasilitas BAIK And Kebersihan KURANG THENKenyamanan CUKUP

[R24] IF Pelayanan KURANG And Fasilitas BAIK And Kebersihan CUKUP THENKenyamanan CUKUP

[R25] IF Pelayanan BAIK And Fasilitas CUKUP And Kebersihan KURANG THENKenyamanan CUKUP

[R26] IF Pelayanan CUKUP And Fasilitas KURANG And Kebersihan BAIK THEN Kenyamanan CUKUP

[R27] IF Pelayanan KURANG And Fasilitas CUKUP And Kebersihan BAIK THEN Kenyamanan CUKUP

Berikut gambaran hasil rules pada setiap variabel input dan output.

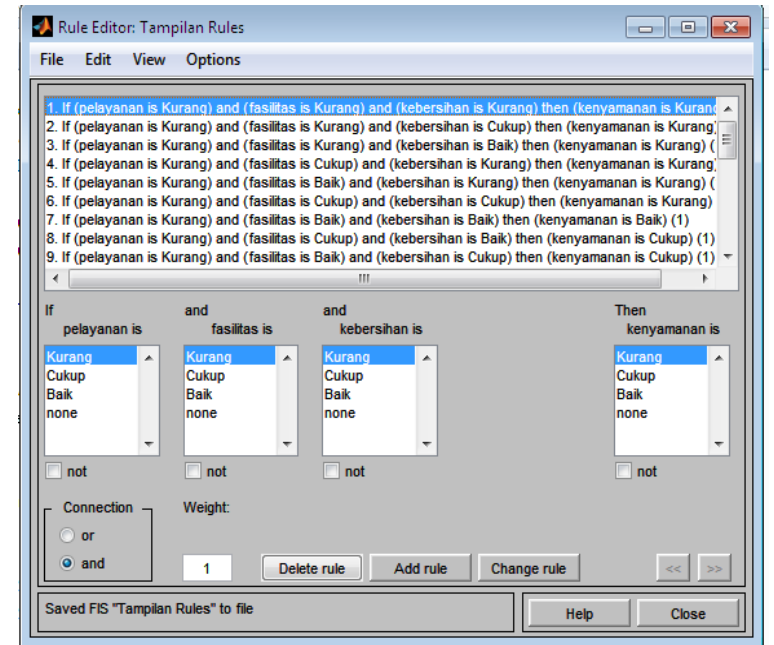

Sumber: (Ma'arif, Samsul ; Sfenrianto; Prayitno, 2019)

Gambar 16. Tampilan Rules

Pada metode Mamdani komposisi antar fungsi implikasi menggunakan MAX yaitu dengan cara mengambil nilai maksimum dari output aturan kemudian menggunakan daerah fuzzy masingmasing. Berikut tampilan hasil surface model Mamdani 


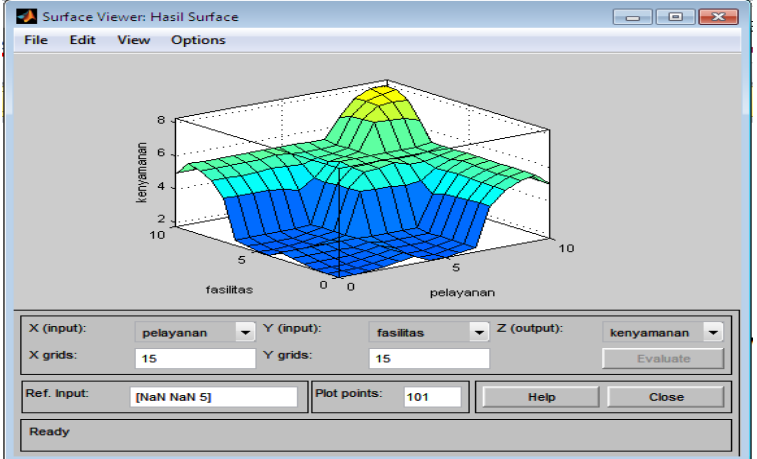

Sumber: (Ma'arif, Samsul ; Sfenrianto; Prayitno, 2019) Gambar 17. Tampilan Surface Viewer

Defuzzyfikasi dilakukan dengan bantuan software Matlab 7.9 toolbox fuzzy. Berikut penalaran fuzzy menggunakan metode Mamdani.

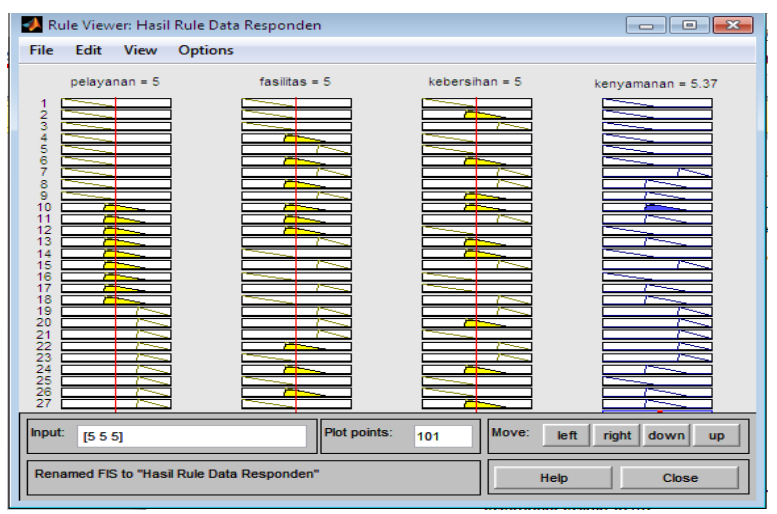

Sumber: (Ma'arif, Samsul ; Sfenrianto; Prayitno, 2019) Gambar 18. Penalaran Fuzzy dengan Metode Mamdani

Hasil pengujian dengan metode centroid dengan input tingkat pelayanan 5 tingkat fasiltas 5 dan tingkat kebersihan 5 menghasilkan output tingkat kenyamanan 5,37.

\section{KESIMPULAN}

Dari hasil penelitian diperoleh bahwa pengukuran tingkat keyamanan pengunjung berdasarkan tingkat pelayanan, fasilitas dan kebersihan di Taman Buah Mekarsari Bogor adalah pelayanan Taman Buah Mekarsari Bogor adalah cukup baik yaitu sebesar 5 yang merupakan keanggotaan dari domain himpunan bilangan fuzzy cukup baik. Tingkat fasilitas dari Taman Buah Mekarsari bogor adalah cukup baik yaitu sebesar 5 yang merupakan keanggotaan dari domain himpunan fuzzy cukup baik. Tingkat Kebersihan dari Taman Buah Mekarsari Bogor adalah cukup baik yaitu sebesar 5. Model Mamdani tingkat kepuasan pengunjung mencapai 5,37 yang merupakan keanggotaan dari domain himpunan fuzzy cukup puas ini berarti pengunjung sudah merasa cukup puas.

\section{REFERENSI}

Badan Pusat Statistik. (2017). Jumlah Kunjungan Wisatawan Ke Obyek Wisata Unggulan Menurut Lokasi 2011-2015. Retrieved from https://jakarta.bps.go.id/Statictable/2017/0 1/30/158/Jumlah-Kunjungan-WisatawanKe-Obyek-Wisata-Unggulan-Menurut-Lokasi2011-2015.Html

Damanik, J. (2014). Meanings, Purposes, And Activities of Suburban Family Tourism In Yogyakarta, Indonesia (U. P. Porananond Dan V. T. King, ed.). Cambridge Scholars Publishing.

Dempsey, C. (2015). Visa Global Travel Intentions Study. Retrieved from https://usa.visa.com/travel-withvisa/global-travel-intentions-study.html

Gokmen, Akinci, Tektas, O. (2010). Evaluation of Student Performance In Laboratory Applications using Fuzzy Logic (Procedia S).

Kusumadewi, S., \& Purnomo, H. (2010). Aplikasi Logika Fuzzy. Jakarta: Graha Ilmu.

Ma'arif, Samsul ; Sfenrianto; Prayitno, E. (2019). Mengukur Tingkat Kenyamanan Pengunjung Taman Buah Mekarsari Bogor Menggunakan Metode Fuzzy Mamdani. Jurnal Ilmu Pengetahuan Dan Teknologi Komputer.

Sastrayuda, G. S. (2010). Hand Out Mata Kuliah Concept Resort and Leisure, Strategi Pengembangan dan Pengelolaan Resort And Leisure. In Hand out resort and leisure. Retrieved from http://file.upi.edu/Direktori/FPIPS/Lainnya/ Gumelar_S/Hand_Out_Matkul_Konsep_Resort _And_Leisure/Pengembangan_Kawasan_Desa _Wisata.Pdf

Satwiko. (2009). Pengertian Kenyamanan Dalam Suatu Bangunan. Yogyakarta: Wignjosoebroto.

Sulistiyana, R. T., Hamid, D., \& Azizah, D. F. (2015). Pengaruh Fasilitas Wisata Dan Harga Terhadap Kepuasan Konsumen (Studi Pada Museum Satwa). Jurnal Administrasi Bisnis S1 Universitas Brawijaya, 25(2), 1-9.

Yoeti, O. A. (2003). Tours And Travel Marketing. Jakarta: Pradnya Paramita. 